\title{
PERANCANGAN BUCK CONVERTER SEBAGAI PENGATURAN LAJU KECEPATAN MOTOR DC PADA GERAK LONGITUDINAL DAN TRANSVERSAL PROTOTYPE OVERHEAD CRANE
}

\author{
Iqbal Anggiawan*), Tejo Sukmadi dan Mochammad Facta \\ Departemen Teknik Elektro, Universitas Diponegoro \\ Jl. Prof. Sudharto, SH, Kampus UNDIP Tembalang, Semarang 50275, Indonesia \\ ${ }^{*}$ E-mail : iqbal.anggiawan@yahoo.com
}

\begin{abstract}
Abstrak
Crane merupakan alat pendukung pada bidang industri, dalam penerapannya beban yang ditanggung oleh crane beragam, maka diperlukan sebuah sistem dalam mengatur kecepatan kerja crane untuk menyesuaikan jenis barang yang ditanggung. Dalam penelitian ini dilakukan perancangan prototype overhead crane dengan penggerak motor DC magnet permanen CSD80A1-A yang di dioperasikan oleh buck converter. Pengaturan kecepatan putar motor DC magnet permanen sebagai penggerak prototype overhead crane dilakukan dengan memvariasikan nilai duty cycle pada buck converter. Prototype overhead crane ini dilakukan pengujian dengan variasi tidak dibebani dan dibebani sebesar $5 \mathrm{~kg}$. Berdasarkan hasil pengukuran buck converter, nilai output terendah terjadi pada gerakan forward transversal tidak dibebani dengan duty cycle $60 \%$ yang menghasilkan daya keluaran 7,74 watt, kecepatan putar 76,53 rpm, dan torsi $0,96 \mathrm{Nm}$. Nilai output tertinggi terjadi pada gerakan forward longitudinal dibebani $5 \mathrm{~kg}$ dengan duty cycle $90 \%$, yang menghasilkan daya keluaran 24,79 watt, kecepatan putar 80,59 rpm, dan torsi 2,93 Nm.
\end{abstract}

Kata kunci :buck converter, prototype overhead crane, SG3524, motor DC magnet permanen

\begin{abstract}
Crane is a supporting tool in the industrial sector, the crane works to lift varietes of loads, so the crane require a system to regulate the speed of crane according to the type of loads. In this research, an overhead crane prototype used permanent magnet CSD80A1-A DC motor is driven by a buck converter. The speed control of permanent magnet DC motor is done by varying the duty cycle on buck converter. The overhead crane prototype is tested in no load and $5 \mathrm{~kg}$ of load. The experimental results show that the lowest output value occurs in no load transverse forward motion at $60 \%$ duty cycle that produces output power 7.74 watt, turn speed $76.53 \mathrm{rpm}$, and torque $0.96 \mathrm{Nm}$. The highest output value occurs in longitudinal forward movement with $5 \mathrm{~kg}$ of load at $90 \%$ duty cycle, and during this condition, the output power is 24,79 watts, turn speed is $80,59 \mathrm{rpm}$, and torque is $2,93 \mathrm{Nm}$.
\end{abstract}

Keywords:buck converter, prototype overhead crane, permanen magnet DC motor.

\section{Pendahuluan}

Seiring dengan perkembangan zaman, manusia dituntut untuk bekerja lebih cepat dan efisien, khususnya pada bidang industri. Untuk menyeimbangkan produk yang sesuai dengan permintaan konsumen maka industri industri dituntut agar meningkatkan hasil produksi serta memperlancar pendistribusian produknya baik itu skala kecil maupun besar. Dalam pendistribusian produk berskala besar diperlukan sebuah alat bantu pemindah (crane) untuk mempercepat dan memperlancar kegiatan produksi[3]. Penerapannya, beban yang ditanggung oleh crane beragam, dari yang kokoh sampai barang pecah belah, maka diperlukan sebuah sistem dalam mengatur kecepatan kerja crane untuk menyesuaikan jenis barang yang ditanggung ketika proses pemindahan.

Motor arus searah (DC) merupakan salah satu jenis motor yang sering digunakan dalam bidang industri, seperti crane, conveyor, lift, dan lain sebagainya. Dikarenakan motor arus searah (DC) memiliki beberapa keunggulan, diantaranya torsi awal yang besar dan metode pengontrolan yang sederhana. Metode dalam pengatur kecepatan motor arus searah (DC) salah satunya adalah menggunakan DC DC converter. Ada berbagai macam jenis DC - DC converter, salah satunya yaitu buck converter[4]. Metode DC chopper dengan jenis buck converter merupakan jenis DC - DC konverter yang menurunkan tegangan dari suplai daya. 
Penelitian mengenai pemanfaatan DC chopper jenis buck sudah dilakukan oleh beberapa peneliti, seperti pada penelitian[1] penggunaan buck converter sebagai penurun tegangan tinggi $300 \mathrm{~V}_{\mathrm{DC}}$. Penelitian[2] membandingkan kinerja buck converter pada kerja CCM dan DCM. Penelitian[12] penggunaan buck converter untuk meningkatkan efisiensi daya pada sistem photovoltaic Penelitian[13] penggunaan buck converter sebagai pembangkit magnet untuk pemisah magnetik dalam konveyor.

Dalam penelitian ini akan dibuat perancangan buck converter sebagai penggerak laju kecepatan putar motor sebagai penggerak prototype overhead crane untuk gerakan longitudinal dan transversal. Penelitian ini menggunakan rangkaian elektronika daya DC chopper tipe buck sebagai catudaya arus searah yang berfungsi sebagai sumber injeksi arus searah pada proses pengaturan kecepatan putar motor arus searah (DC) pada prototype overhead crane. Sehingga injeksi arus searah pada pengaturan kecepatan motor DC dapat divariasikan sesuai dengan keadaan motor dan kebutuhan proses operasi sistem.

\section{Metode}

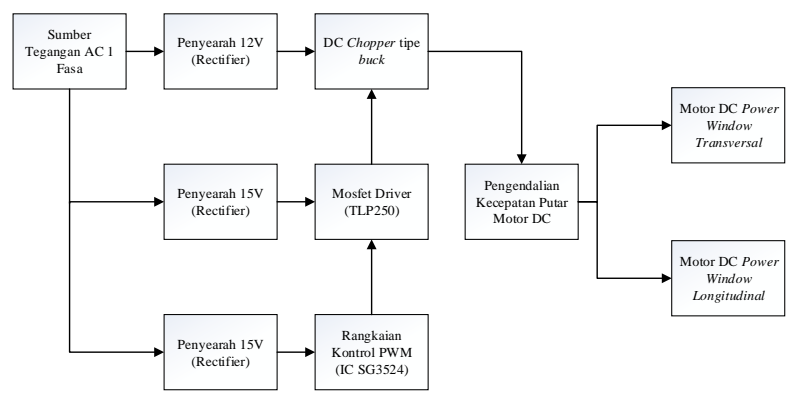

Gambar 1. Blok diagram perancangan

Gambar 1. diagram alir perancangan penelitian secara keseluruhan. Sumber tegangan arus bolak balik (AC) satu fasa merupakan sumber utama untuk suplai masing masing rectifier. Sumber tegangan 1 fasa $220 \mathrm{~V}$ disearahkan menggunakan rectifier menjadi $12 \mathrm{~V}$ pada suplai rangkaian daya DC chopper tipe buck. Suplai rangkaian kontrol PWM (IC SG3524) dan MOSFET Driver TLP250 menggunakan taping trafo $15 \mathrm{~V}$. Rangkaian kontrol PWM (IC SG3524) dan Mosfet Driver (TLP250) akan memicu MOSFET pada DC chopper tipe buck. Blok pengendalian kecepatan putar motor DC berfungsi untuk mengatur arah putar dari si motor untuk gerakan transversal dan longitudinal.

\subsection{Motor DC Power Window CSD80A1-A}

Motor DC power window merupakan salah satu jenis motor DC magnet permanen. Motor DC power window CSD80A1-A akan digunakan sebagai penggerak pada perancangan prototype overhead crane, dengan suplai tegangan $12 \mathrm{~V}$. Nilai resistansi dan induktansi pada motor DC power window CSD80A1-A sebesar 19,612 $\Omega$ dan 1 $\mathrm{mH}$.

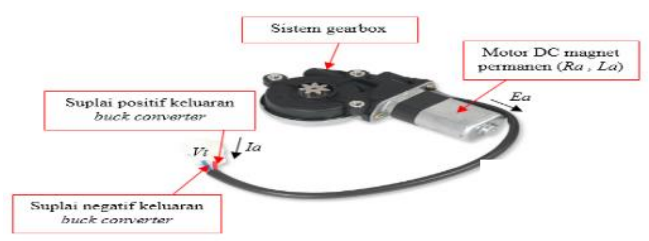

Gambar 2. Motor DC power window CSD80A1-A

Tabel 1. Motor DC Power Window CSD80A1-A[5]

\begin{tabular}{ll}
\hline Spesifikasi CSD80A1-A & Nilai \\
\hline Torsi maksimum & $3 \mathrm{Nm}$ \\
Kecepatan tanpa beban & $\geq 90 \mathrm{rpm}$ \\
Rating tegangan & $12 \mathrm{Volt}$ \\
Arus tanpa beban & $\leq 1,5$ ampere \\
\hline
\end{tabular}

\subsection{Buck Converter}

DC Chopper jenis Buck digunakan sebagai sumber tegangan DC untuk suplai motor DC power window sebagai penggerak ptototype overhead crane. Parameter penting yang harus diperhatikan dalam pemilihan komponen MOSFET yaitu nilai tegangan dan arus kerja MOSFET. Penelitian ini nilai tegangan dan arus yang bekerja pada MOSFET sebesar 16,9 $\mathrm{V}_{\mathrm{dc}}$ dan $5 \mathrm{~A}$. Penelitian ini digunakan MOSFET tipe IRFP460 sebagai piranti pensaklaran karena spesifikasinya telah memadai[6]

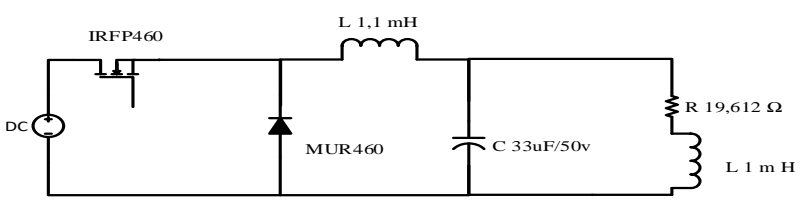

Gambar 3. Rangkaian buck converter

\subsection{Rangkaian Kontrol Pembangkit Sinyal PWM IC SG3524}

Rangkaian kontrol IC SG3524 digunakan sebagai penghasil sinyal PWM (Pulse Width Modulation). Rangkaian kontrol IC SG3524 dapat mengatur nilai frekuensi dan duty cycle dari gelombang PWM. Nilai frekuensi osilasi pada IC SG3524 diatur oleh dua jenis komponen yang dihubungkan oleh pin 6 dan 7. Pin 6 pada IC SG3524 adalah $R_{T}$ (Resistor Timer) dan pin 7 adalah $C_{T}$ (Capasitor Timer). Persamaan unutk mencari nilai frekuensi maksimum yang sesuai pada datasheet IC SG3524 dituliskan oleh persamaan (1)[7] berikut :

$$
\begin{array}{ll}
f=\frac{1,3}{R_{T} C_{T}} & \\
C_{T} & =0,001 \mu \mathrm{F} \\
R_{T} & =47 \mathrm{k} \Omega \\
R_{\mathrm{var}} & =10 \mathrm{k} \Omega
\end{array}
$$




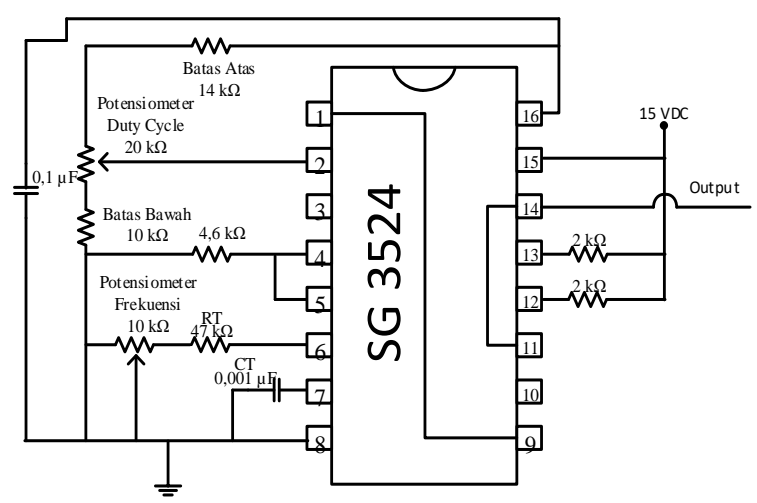

Gambar 4. Rangkaian kontrol IC SG3524.

\subsection{Rangkaian MOSFET Driver IC TLP250}

Rangkaian MOSFET driver IC TLP250 digunakan untuk menguatkan sinyal PWM (Pulse Width Modulation) dan untuk mengisolasi[8]. Ground antara IC TLP250 dengan IC SG3524 terpisah sebagai fungsi isolasi antara rangkaian kontrol dan daya.

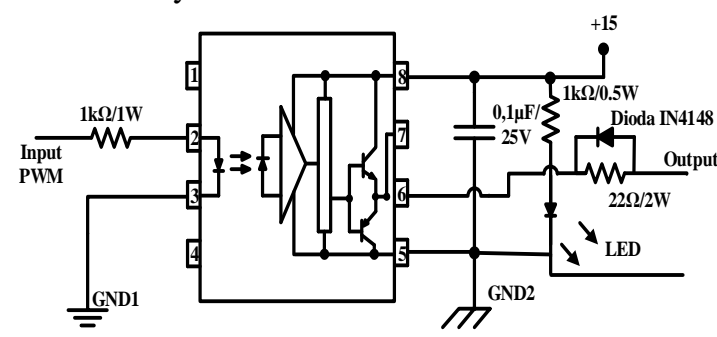

Gambar 5. Rangkaian MOSFET driver IC TLP250

\section{Hasil dan Analisa}

\subsection{Pengujian Gelombang Keluaran Rangkaian Kontrol}

Pengujian gelombang keluaran rangkaian kontrol, bertujuan untuk memastikan bahwa gelombang tegangan keluaran telah sesuai dengan perancangan. Rangkaian PWM buck converter pada penelitian ini menggunakan IC SG3524 dengan satu keluaran (Single - ended). Kaki pin 14 dari IC SG3524 sebagai masukan pemicuan gate MOSFET. Pengujian ini dilakukan dengan pin 6 pada MOSFET driver TLP250 sebagai keluarannya dan pin 5 sebagai ground, dengan probe tegangan $\mathrm{x} 1$.

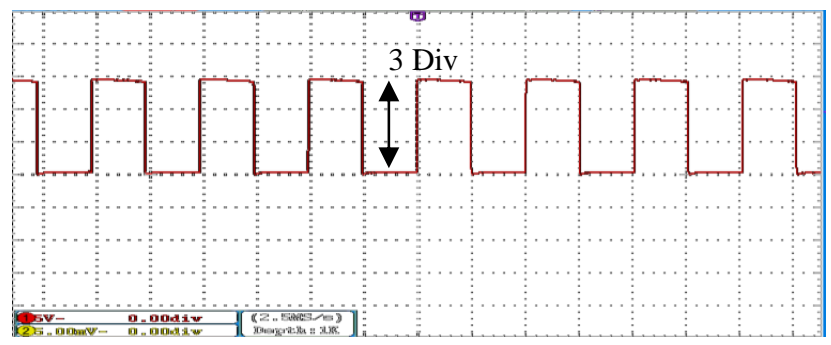

Gambar 6. Gelombang keluaran rangkaian kontrol
Gelombang keluaran rangkaian kontrol menjelaskan bahwa tegangan keluaran rangkaian kontrol buck converter berupa gelombang tegangan Vpp (peak to peak) sebesar:

Vpp $\quad=3 \operatorname{div} \times 5 \mathrm{~V} / \operatorname{div} \times 1$

$=15$ Volt

Berdasarkan perhitungan didapat nilai tegangan keluaran (Vpp) dari rangkaian kontrol IC SG3524 dengan MOSFET driver TLP250 sebesar 15 volt. Tegangan keluaran tersebut sudah dapat mensuplai MOSFET IRFP460 dengan baik, karena berdasarkan datasheet MOSFET IRFP460 dapat disuplai dengan tegangan minimal sebesar $4 \mathrm{~V}$ dan maksimal sebesar $500 \mathrm{~V}[21]$

\subsection{Pengujian Rangkaian Buck Converter}

Pengujian pada variasi beban resistif dan resistif induktif ini merupakan sebuah uji alat dari buck converter sebelum di lakukan pada motor DC power window yang digunakan sebagai penggerak pada prototype overhead crane pada gerakan transversal dan longitudinal. Nilai dari variasi beban resistif dan resistif induktif ini sendiri juga didapat dari nilai resistansi serta induktansi pada motor DC power window pada prototype overhead crane, yaitu sebesar $19,612 \Omega$ dan $1 \mathrm{mH}$. Pengujian ini dilakukan pada range duty cycle $15 \%$ - $90 \%$ dan frekuensi $25 \mathrm{kHz}$.

\subsubsection{Pengujian Tegangan Keluaran dengan Beban Resistif dan Resistif Induktif}

Pengujian ini dilakukan untuk mengetahui nilai tegangan keluaran yang dihasilkan oleh buck converter.

Tabel 2. Hasil pengujian tegangan keluaran buck converter dengan beban resistif dan resistif induktif

\begin{tabular}{ccccc}
\hline Beban & $\begin{array}{c}\text { Duty } \\
\text { Cycle } \\
\text { (\%) }\end{array}$ & $\begin{array}{c}\text { Frekuensi } \\
\text { (kHz) }\end{array}$ & $\begin{array}{c}\text { Tegangan } \\
\text { masukan } \\
\text { (Volt) }\end{array}$ & $\begin{array}{c}\text { Tegangan } \\
\text { keluaran } \\
\text { (Volt) }\end{array}$ \\
\hline \multirow{6}{*}{ Resistif } & 15 & 25 & 16,64 & 2,35 \\
& 30 & 25 & 16,27 & 4,47 \\
& 45 & 25 & 16,01 & 6,8 \\
& 60 & 25 & 15,58 & 8,91 \\
& 75 & 25 & 15,1 & 10,73 \\
& 90 & 25 & 14,66 & 12,88 \\
& 15 & 25 & 16,34 & 2,16 \\
Resistif & 30 & 25 & 16,13 & 4,26 \\
& 45 & 25 & 15,23 & 5,58 \\
& 60 & 25 & 13,88 & 7,51 \\
& 75 & 25 & 11,4 & 8,24 \\
\hline
\end{tabular}

Berdasarkan data yang diperoleh pada Tabel 2 maka dapat dibuat grafik hubungan antara duty cycle dengan tegangan keluaran. Gambar 7 merupakan grafik perbandingan duty cycle dengan tegangan keluaran beban resistif dan tresistif induktif. 


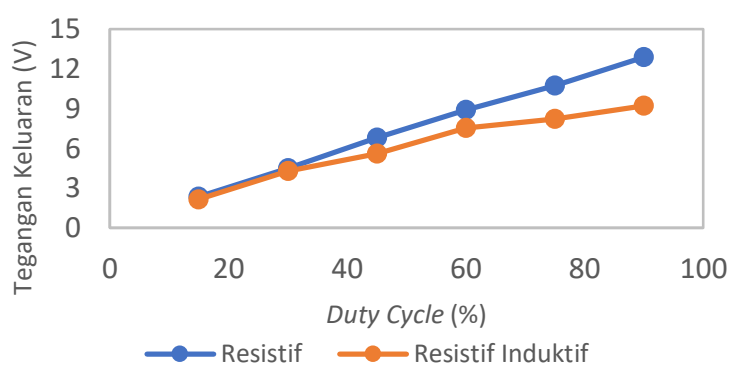

Gambar 7. Grafik perbandingan duty cycle dengan tegangan keluaran beban resistif dan resistif induktif

Berdasarkan Gambar 7 menunjukan bahwa semakin besar picu duty cycle, semakin tinggi pula nilai tegangan keluaran yang dihasilkan oleh buck converter. Gambar 7 menunjukan hubungan antara duty cycle dengan tegangan keluaran berbanding lurus.

\subsubsection{Pengujian Arus Keluaran dengan Beban Resistif dan Resistif Induktif}

Pengujian ini dilakukan untuk mengetahui karakter dan nilai arus keluaran yang dihasilkan oleh buck converter.

Tabel 3. Hasil pengujian arus keluaran buck converter dengan beban resistif dan resistif induktif

\begin{tabular}{ccccc}
\hline Beban & $\begin{array}{c}\text { Duty } \\
\text { Cycle } \\
\text { (\%) }\end{array}$ & $\begin{array}{c}\text { Frekuensi } \\
\text { (kHz) }\end{array}$ & $\begin{array}{c}\text { Arus } \\
\text { masukan } \\
\text { (Ampere) }\end{array}$ & $\begin{array}{c}\text { Arus } \\
\text { keluaran } \\
\text { (Ampere) }\end{array}$ \\
\hline \multirow{5}{*}{ Resistif } & 15 & 25 & 0,02 & 0,1 \\
& 30 & 25 & 0,07 & 0,21 \\
& 45 & 25 & 0,15 & 0,32 \\
& 60 & 25 & 0,26 & 0,42 \\
& 75 & 25 & 0,39 & 0,52 \\
Resistif & 90 & 25 & 0,57 & 0,62 \\
Induktif & 15 & 25 & 0,04 & 0,19 \\
& 30 & 25 & 0,17 & 0,49 \\
& 45 & 25 & 0,42 & 0,93 \\
& 60 & 25 & 0,8 & 1,26 \\
& 75 & 25 & 1,21 & 1,46 \\
\hline
\end{tabular}

Berdasarkan tabel 3 maka dapat dibuat grafik hubungan antara duty cycle dengan arus keluaran.

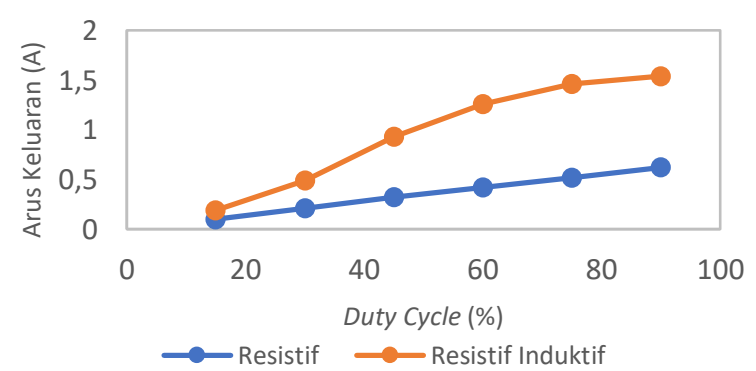

Gambar 8. Grafik perbandingan duty cycle dengan arus keluaran beban resistif dan resistif induktif
Berdasarkan Gambar 8 menunjukan bahwa semakin besar duty cycle, semakin tinggi pula nilai arus keluaran yang dihasilkan oleh buck converter. Gambar 8 menunjukan hubungan antara duty cycle dengan tegangan keluaran berbanding lurus.

\subsubsection{Perhitungan Efisiensi Buck Converter dengan Beban Resistif dan Resistif Induktif}

Berdasarkan tabel 2 dan tabel 3 dapat dicari nilai efisiensi pada buck converter dengan cara menghitung besar daya input $\left(\mathrm{P}_{\text {in }}\right)$ dan daya output $\left(\mathrm{P}_{\text {out }}\right)$ masing masing percobaan, dengan menggunakan persamaan (2)

$\eta=\frac{P_{\text {out }}}{P_{\text {in }}} \times 100 \%$

Dimana:

$\mathrm{P}_{\text {in }} \quad=\mathrm{V}_{\text {in }} \quad \mathrm{X} \quad \mathrm{I}_{\text {in }}$

$\mathrm{P}_{\text {out }}=\mathrm{V}_{\text {out }} \quad \mathrm{X} \quad \mathrm{I}_{\text {out }}$

Dengan menggunakan persamaan (1), maka didapatkan data efisiensi pada tabel 4

Tabel 4. Data perhitungan efisiensi buck converter pembebanan resistif dan resistif induktif

\begin{tabular}{ccccc}
\hline Beban & $\begin{array}{c}\text { Duty Cycle } \\
(\%)\end{array}$ & Pin (Watt) & $\begin{array}{c}\text { Pout } \\
\text { (Watt) }\end{array}$ & Efisiensi (\%) \\
\hline \multirow{5}{*}{ Resistif } & 15 & 0,32 & 0,23 & 71,51 \\
& 30 & 1,13 & 0,93 & 82,42 \\
& 45 & 2,4 & 2,17 & 90,61 \\
& 60 & 4,05 & 3,74 & 92,38 \\
& 75 & 5,88 & 5,57 & 94,74 \\
Resistif & 90 & 8,35 & 7,98 & 95,56 \\
Induktif & 15 & 0,65 & 0,41 & 62,79 \\
& 30 & 2,74 & 2,08 & 76,12 \\
& 45 & 6,39 & 5,18 & 81,12 \\
& 75 & 11,1 & 9,46 & 85,21 \\
& 90 & 13,79 & 12,03 & 87,21 \\
& & 14,977 & 14,18 & 94,69 \\
\hline
\end{tabular}

Berdasarkan data perhitungan efisiensi buck converter pembebanan resisitif dan resistif induktif yang tertera pada tabel 4, maka dapat dibuat grafik perbandingan antara duty cycle dengan nilai efisiensi.

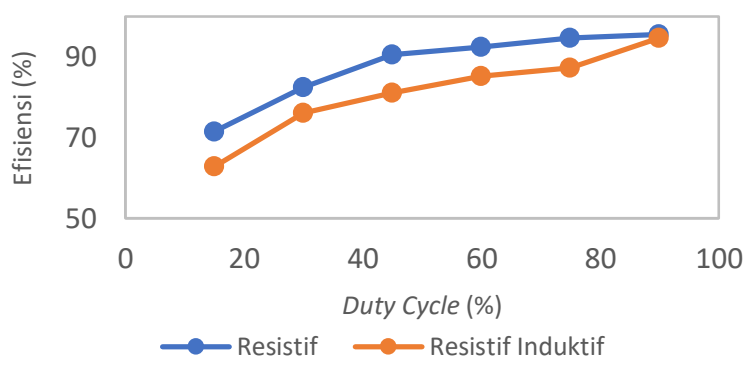

Gambar 9. Grafik perbandingan duty cycle dengan efisiensi buck converter beban resistif dan resistif induktif 
Gambar 9 menunjukkan bahwa pada saat frekuensi $25 \mathrm{kHz}$ seiring naiknya nilai duty cycle, maka nilai efisiensi buck converter akan semakin naik. Nilai efisiensi tertinggi yang dihasilkan pada buck converter beban resistif dan resistif induktif terjadi pada saat duty cycle $90 \%$, yaitu sebesar $95,56 \%$ dan $94,69 \%$. Nilai efisiensi terendah terjadi pada saat duty cycle $15 \%$ yaitu bernilai $71,51 \%$ dan

$62,79 \%$. Efisiensi rata - rata pada rangkaian buck converter pembebanan resistif $20 \Omega$ dan induktif $1 \mathrm{mH}$ dengan nilai frekuensi $25 \mathrm{kHz}$ sebesar $87,87 \%$ dan $81,19 \%$.

\subsection{Pengujian Aplikasi Buck Converter pada Motor Penggerak Prototype Overhead Crane.}

Pengujian aplikasi buck converter pada motor penggerak prototype overhead crane sebagai pengatur laju kecepatan putar motor. Pengujian dilakukan dengan frekuensi $25 \mathrm{kHz}$ dengan variasi duty cycle $60 \%$ - $90 \%$ pada dua gerakan prototype overhead crane yaitu gerakan longitudinal dan transversal dengan variasi forward-reverse. Nilai hasil pengukuran pada variasi forward-reverse relatif sama. Untuk memperingkas laporan, maka diambil data variasi forward sebagai contoh variasi forward-reverse.

\subsubsection{Pengujian Aplikasi Buck Converter pada Gerakan Forward Longitudinal}

Pengujian pada gerakan ini, forward longitudinal dilakukan dalam dua variasi yaitu pengujian tanpa dibebani dan dibebani. Beban yang digunakan pada variasi pengujian dibebani sebesar $5 \mathrm{~kg}$.

Tabel 5. Data pengukuran gerakan forward longitudinal

\begin{tabular}{cccccc}
\hline Kondisi & $\begin{array}{c}\text { Duty } \\
\text { Cycle } \\
(\%)\end{array}$ & $\begin{array}{c}\text { Tegangan } \\
\text { Masukan } \\
\text { (Volt) }\end{array}$ & $\begin{array}{c}\text { Arus } \\
\text { Masukan } \\
\text { (Ampere) }\end{array}$ & $\begin{array}{c}\text { Tegangan } \\
\text { Keluaran } \\
\text { (Volt) }\end{array}$ & $\begin{array}{c}\text { Arus } \\
\text { Keluaran } \\
\text { (Ampere) }\end{array}$ \\
\hline \multirow{2}{*}{ Tidak } & 60 & 14,65 & 1,19 & 7,86 & 1,35 \\
dibebani & 75 & 13,32 & 1,28 & 9,83 & 1,41 \\
& 90 & 12,98 & 1,49 & 11,4 & 1,59 \\
& 60 & 13,29 & 1,26 & 7,45 & 1,87 \\
Dibebani & 75 & 12,65 & 1,63 & 9,01 & 1,98 \\
& 90 & 12,56 & 1,98 & 11,02 & 2,25 \\
\hline
\end{tabular}

Berdasarkan tabel 5, maka dapat dapat dibuat grafik perbandingan antara duty cycle dengan tegangan keluaran dan duty cycle dengan arus keluaran.

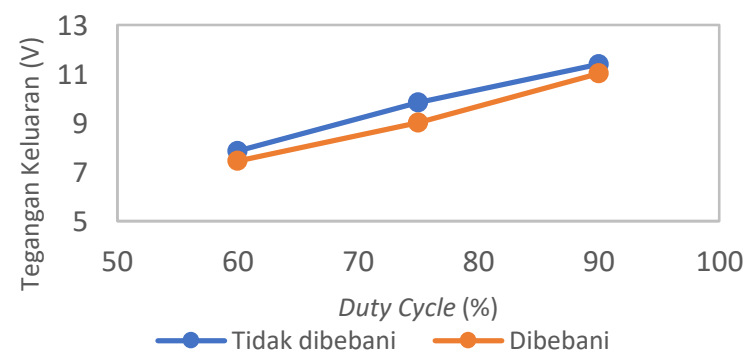

Gambar 10. Grafik perbandingan duty cycle dengan tegangan keluaran forward longitudinal
Berdasarkan gambar 10 dapat dilihat bahwa hasil pengukuran yang diperoleh sudah sesuai dengan teori karakteristik DC - DC converter tipe buck, dimana buck converter memiliki karakteristik menurunkan tegangan keluaran dari tegangan masukan. Gambar 10 juga dapat dilihat, hubungan antara duty cycle dengan tegangan keluaran berbanding lurus, semakin besar nilai duty cycle, maka semakin besar pula nilau tegangan keluaran.

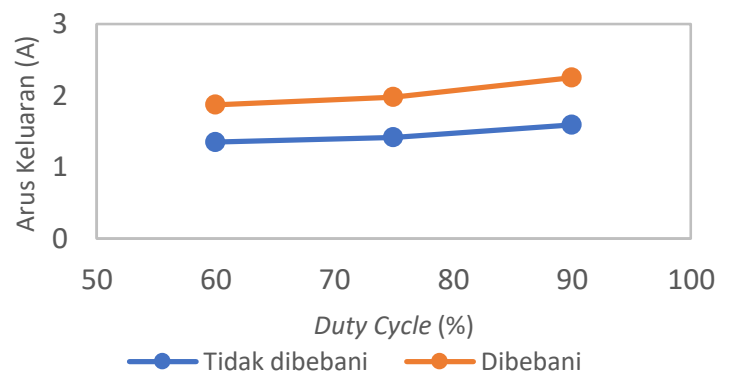

Gambar 11. Grafik perbandingan duty cycle dengan arus keluaran forward longitudinal

Berdasarkan gambar 11 dapat dilihat bahwa semakin besar nilai duty cycle maka semakin besar pula nilai arus keluaran yang dihasilkan buck converter.

\subsubsection{Pengujian Aplikasi Buck Converter pada Gerakan Forward Transversal}

Pengujian pada gerakan ini, forward transversal dilakukan dalam dua variasi yaitu pengujian tanpa dibebani dan dibebani. Beban yang digunakan pada variasi pengujian dibebani sebesar $5 \mathrm{~kg}$.

Tabel 6. Data pengukuran gerakan forward transversal

\begin{tabular}{cccccc}
\hline Kondisi & $\begin{array}{c}\text { Duty } \\
\text { Cycle } \\
(\%)\end{array}$ & $\begin{array}{c}\text { Tegangan } \\
\text { Masukan } \\
\text { (Volt) }\end{array}$ & $\begin{array}{c}\text { Arus } \\
\text { Masukan } \\
\text { (Ampere) }\end{array}$ & $\begin{array}{c}\text { Tegangan } \\
\text { Keluaran } \\
\text { (Volt) }\end{array}$ & $\begin{array}{c}\text { Arus } \\
\text { Keluaran } \\
\text { (Ampere) }\end{array}$ \\
\hline Tidak & 60 & 15,02 & 0,71 & 8,42 & 0,92 \\
dibebani & 75 & 14,39 & 0,89 & 10,45 & 1,08 \\
& 90 & 14,26 & 1,18 & 12,02 & 1,32 \\
& 60 & 14,78 & 0,79 & 8,04 & 1,23 \\
Dibebani & 75 & 13,89 & 1,07 & 10,02 & 1,34 \\
& 90 & 13,65 & 1,27 & 11,53 & 1,46 \\
\hline
\end{tabular}

Berdasarkan tabel 6, maka dapat dapat dibuat grafik perbandingan antara duty cycle dengan tegangan keluaran dan duty cycle dengan arus keluaran.

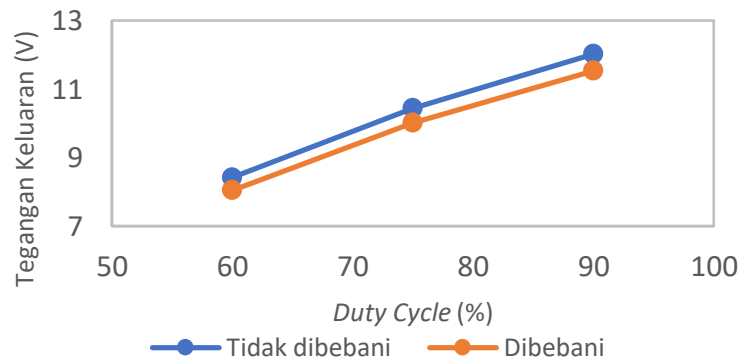

Gambar 12. Grafik perbandingan duty cycle dengan tegangan keluaran forward transversal 
Berdasarkan gambar 12 dapat dilihat bahwa hasil pengukuran yang diperoleh sudah sesuai dengan teori karakteristik DC - DC converter tipe buck, dimana buck converter memiliki karakteristik menurunkan tegangan keluaran dari tegangan masukan. Gambar 12 juga dapat dilihat, hubungan antara duty cycle dengan tegangan keluaran berbanding lurus, semakin besar nilai duty cycle, maka semakin besar pula nilau tegangan keluaran.

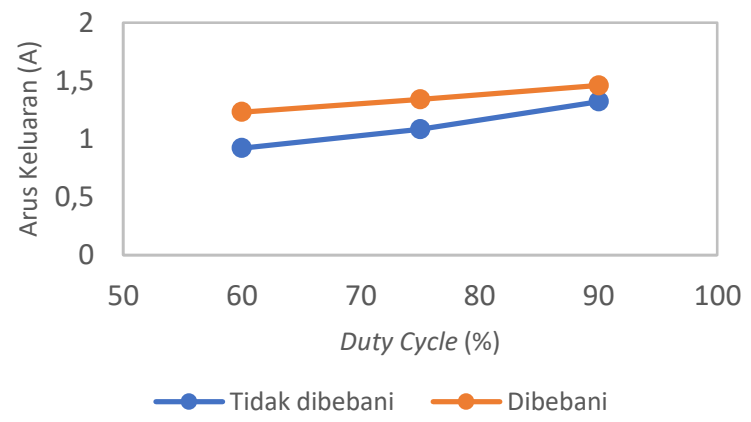

Gambar 13. Grafik perbandingan duty cycle dengan arus keluaran forward transversal

Berdasarkan gambar 13 dapat dilihat bahwa semakin besar nilai duty cycle maka semakin besar pula nilai arus keluaran yang dihasilkan buck converter.

\subsection{Perhitungan Nilai Efisiensi Buck Converter Gerakan Longitudinal dan Transversal.}

Nilai efisiensi buck converter dapat ditemukan dengan cara menghitung daya input $\left(\mathrm{P}_{\text {in }}\right)$ dan daya output $\left(\mathrm{P}_{\text {out }}\right)$ pada buck converter pada masing-masing percobaan, dengan menggunakan persamaan (2). Nilai hasil pengukuran pada variasi forward-reverse relatif sama, untuk memperingkas laporan, maka diambil data variasi forward sebagai contoh variasi forward-reverse.

\subsubsection{Perhitungan Nilai Efisiensi Buck Converter Gerakan Forward Longitudinal.}

Dengan menggunakan persamaan (2) untuk mencari nilai efisiensi buck converter, maka didapat data nilai efisiensi buck converter pada gerakan forward longitudinal.

Tabel 7. Data perhitungan efisiensi gerakan forward longitudinal

\begin{tabular}{ccccc}
\hline Kondisi & $\begin{array}{c}\text { Duty } \\
\text { Cycle } \\
\text { (\%) }\end{array}$ & $\begin{array}{c}\text { Daya } \\
\text { masukan } \\
\text { (Watt) }\end{array}$ & $\begin{array}{c}\text { Daya } \\
\text { Keluaran } \\
\text { (Watt) }\end{array}$ & $\begin{array}{c}\text { Efisiensi } \\
\text { (\%) }\end{array}$ \\
\hline Tidak & 60 & 17,43 & 10,61 & 60,87 \\
dibebani & 75 & 17,04 & 13,86 & 81,29 \\
& 90 & 19,34 & 18,12 & 93,72 \\
Dibebani & 60 & 16,74 & 13,93 & 83,2 \\
& 75 & 20,61 & 17,83 & 86,52 \\
& 90 & 24,86 & 24,79 & 99,7 \\
\hline
\end{tabular}

Berdasarkan tabel 7, dapat digambarkan grafik perbandingan antara duty cycle dengan efisiensi buck converter gerakan longitudinal.

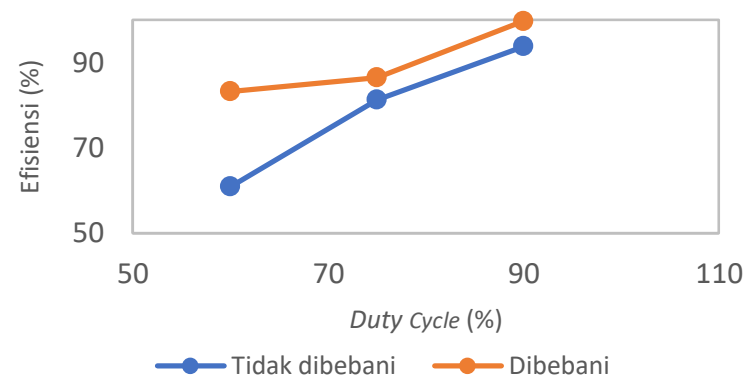

Gambar 14. Grafik perbandingan duty cycle dengan efisiensi buck converter gerakan forward longitudinal.

Berdasarkan gambar 14, dapat dilihat bahwa seiring kenaikan nilai picuan duty cycle maka semakin tinggi nilai efisiensi buck converter. nilai efisiensi tertinggi dihasilkan oleh duty cycle $90 \%$ pada kondisi tidak dibebani dan dibebani sebesar $93,72 \%$ dan $99,7 \%$, sedangkan yang terendah duty cycle $60 \%$ bernilai $60,87 \%$ dan $83,2 \%$. Pada Tabel 4.8 dapat diperoleh rata - rata nilai efisiensi pada kondisi tidak dibebani dan dibebani sebesar 78,62\% dan $89,9 \%$.

\subsubsection{Perhitungan Nilai Efisiensi Buck Converter Gerakan Forward Transversal.}

Dengan menggunakan persamaan (2) untuk mencari nilai efisiensi buck converter, maka didapat data nilai efisiensi buck converter pada gerakan forward transversal.

Tabel 8. Data perhitungan efisiensi gerakan forward transversal

\begin{tabular}{ccccc}
\hline Kondisi & $\begin{array}{c}\text { Duty } \\
\text { Cycle } \\
(\%)\end{array}$ & $\begin{array}{c}\text { Daya } \\
\text { masukan } \\
\text { (Watt) }\end{array}$ & $\begin{array}{c}\text { Daya } \\
\text { Keluaran } \\
\text { (Watt) }\end{array}$ & $\begin{array}{c}\text { Efisiensi } \\
(\%)\end{array}$ \\
\hline Tidak & 60 & 10,66 & 7,74 & 72,64 \\
dibebani & 75 & 12,8 & 11,28 & 88,12 \\
& 90 & 16,82 & 15,86 & 94,29 \\
Dibebani & 60 & 11,67 & 9,88 & 84,7 \\
& 75 & 14,86 & 13,42 & 90,34 \\
& 90 & 17,33 & 16,83 & 97,11 \\
\hline
\end{tabular}

Berdasarkan tabel 8, dapat digambarkan grafik perbandingan antara duty cycle dengan efisiensi buck converter gerakan forward transversal.

Berdasarkan gambar 15, dapat dilihat bahwa seiring kenaikan nilai picuan duty cycle maka semakin tinggi nilai efisiensi buck converter. nilai efisiensi tertinggi dihasilkan oleh duty cycle $90 \%$ pada kondisi tidak dibebani dan dibebani sebesar $94,29 \%$ dan $97,11 \%$, sedangkan yang terendah duty cycle $60 \%$ bernilai $72,64 \%$ dan $84,7 \%$. Pada Tabel 4.8 dapat diperoleh rata - rata nilai efisiensi pada kondisi tidak dibebani dan dibebani sebesar $85,02 \%$ dan $90,71 \%$ 


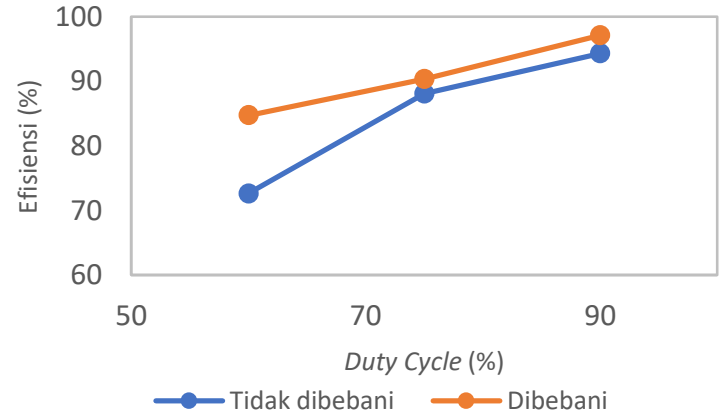

Gambar 15. Grafik perbandingan duty cycle dengan efisiensi buck converter gerakan forward transversal.

\subsection{Perhitungan Nilai Torsi}

Perhitungan nilai torsi ini dilakukan pada masing - masing motor DC power window CSD80A1-A penggerak longitudinal dan transversal dengan mode operasi forward - reverse serta kondisi tidak dibebani dan dibebani. Perhitungan ini dilakukan pada variasi duty cycle $60 \%$ $90 \%$. Nilai torsi dapat dihitung menggunakan persamaan (3) - persamaan (7). $v=\frac{s}{t}$

$\omega=\frac{v}{r}$

$n=9,55 \times \omega$

$\tau=\frac{P \times 9,55}{n}$

Dengan:

$P=$ Daya pada motor $(\mathrm{W})$

$\tau=$ Torsi (N.m)

$n=\operatorname{Kecepatan} \operatorname{putar}(\mathrm{rpm})$

$\omega=$ Kecepatan sudut (rad/detik)

$v=\operatorname{Kecepatan}(\mathrm{m} /$ detik $)$

$r=$ Jari - jari $(\mathrm{m})$

$S=\operatorname{Jarak}$ tempuh $(\mathrm{m})$

$t=$ Waktu tempuh (detik)

Nilai hasil pengukuran pada variasi forward-reverse relatif sama, untuk memperingkas laporan, maka diambil data variasi forward sebagai contoh variasi forwardreverse.

\subsubsection{Perhitungan Nilai Torsi pada Gerakan Forward Longitudinal}

Panjang lintasan gerakan longitudinal pada prototype overhead crane ini sebesar 1,2 $\mathrm{m}$ dan jari jari gigi pada motor sebesar 0,03 m. Dengan menggunakan persamaan (3) - persamaan (7) didapat data sebagai berikut.
Tabel 10. Data perhitungan nilai torsi gerakan forward longitudinal

\begin{tabular}{cccccccc}
\hline Kondisi & $\begin{array}{c}\text { Duty } \\
\text { cycle } \\
\text { (\%) }\end{array}$ & $\begin{array}{c}\boldsymbol{t} \\
\text { (detik) }\end{array}$ & $\begin{array}{c}\boldsymbol{P} \\
\text { (W) }\end{array}$ & $\begin{array}{c}\boldsymbol{V} \\
\text { (m/detik) }\end{array}$ & $\begin{array}{c}\boldsymbol{\omega} \\
\text { (rad/detik) }\end{array}$ & $\begin{array}{c}\boldsymbol{n} \\
\text { (rpm) }\end{array}$ & $\begin{array}{c}\boldsymbol{\tau} \\
\text { (N.m) }\end{array}$ \\
\hline Tidak & 60 & 7,5 & 10,61 & 0,16 & 5,33 & 50,93 & 1,98 \\
dibebani & 75 & 5,95 & 13,86 & 0,2 & 6,72 & 64,2 & 2,06 \\
& 90 & 4,74 & 18,12 & 0,25 & 8,43 & 80,59 & 2,14 \\
& 60 & 8,18 & 13,93 & 0,14 & 4,88 & 46,69 & 2,84 \\
Dibebani & 75 & 6,53 & 17,83 & 0,18 & 6,12 & 58,49 & 2,91 \\
& 90 & 4,79 & 24,79 & 0,25 & 8,35 & 79,74 & 2,96 \\
\hline
\end{tabular}

Dari tabel 10 dapat dibuat grafik perbandingan antara duty cycle dengan torsi seperti gambar berikut.

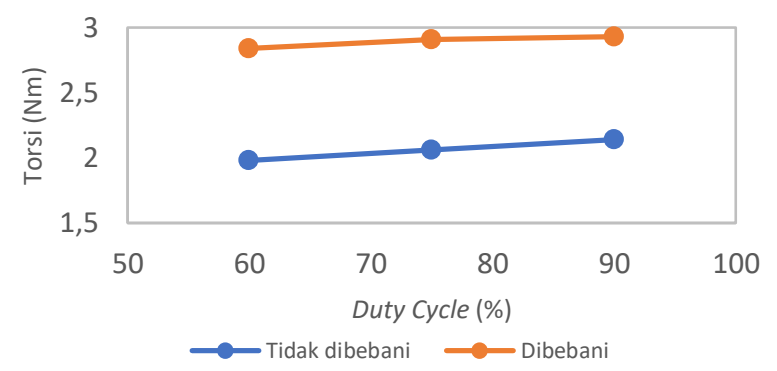

Gambar 16. Grafik perbandingan duty cycle dengan torsi gerakan forward longitudinal.

Berdasarkan gambar 16, dapat dilihat bahwa nilai torsi pada gerak forward dan reverse longitudinal kondisi dibebani lebih besar daripada kondisi tidak dibebani.

(6) Seperti pada picuan duty cycle $90 \%$, pada gerakan forward longitudinal nilai torsi kondisi tidak dibebani adalah 2,04 $\mathrm{Nm}$, sedangkan pada kondisi dibebani 2,96 Nm.

\subsubsection{Perhitungan Nilai Torsi pada Gerakan Forward Transversal}

Panjang lintasan gerakan transversal pada prototype overhead crane ini sebesar $0,88 \mathrm{~m}$ dan jari jari gigi pada motor sebesar $0,03 \mathrm{~m}$. Dengan menggunakan persamaan (3) - persamaan (7) didapat data sebagai berikut.

Tabel 11. Data perhitungan nilai torsi gerakan forward transversal

\begin{tabular}{cccccccc}
\hline Kondisi & $\begin{array}{c}\text { Duty } \\
\text { cycle } \\
(\%)\end{array}$ & $\begin{array}{c}\boldsymbol{t} \\
\text { (detik) }\end{array}$ & $\begin{array}{c}\boldsymbol{P} \\
(\mathbf{W})\end{array}$ & $\begin{array}{c}\boldsymbol{V} \\
\text { (m/detik) }\end{array}$ & $\begin{array}{c}\boldsymbol{\omega} \\
\text { (rad/detik) }\end{array}$ & $\begin{array}{c}\boldsymbol{n} \\
(\mathbf{r p m})\end{array}$ & $\begin{array}{c}\boldsymbol{\tau} \\
(\mathbf{N} . \mathrm{m})\end{array}$ \\
\hline \multirow{2}{*}{ Tidak } & 60 & 3,66 & 7,74 & 0,24 & 8,01 & 76,53 & 0,96 \\
dibebani & 75 & 2,88 & 11,28 & 0,3 & 10,18 & 97,26 & 1,1 \\
& 90 & 2,5 & 15,86 & 0,35 & 11,73 & 112,05 & 1,35 \\
& 60 & 4,26 & 9,88 & 0,2 & 6,88 & 65,75 & 1,43 \\
Dibebani & 75 & 3,19 & 13,42 & 0,27 & 9,19 & 87,81 & 1,46 \\
& 90 & 2,61 & 16,83 & 0,33 & 11,23 & 107,33 & 1,49 \\
\hline
\end{tabular}


Dari tabel 11 dapat dibuat grafik perbandingan antara duty cycle dengan torsi seperti gambar berikut.

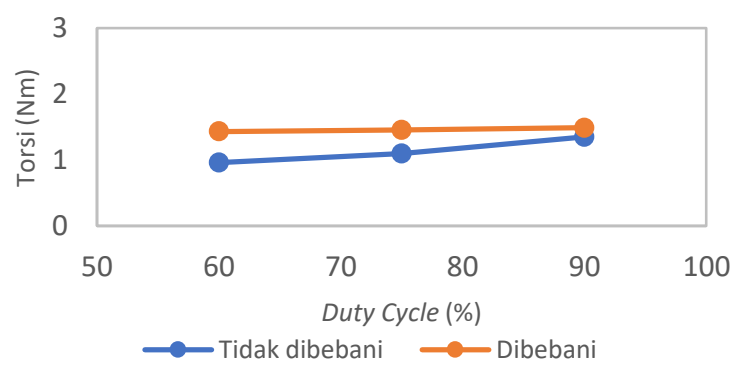

Gambar 17. Grafik perbandingan duty cycle dengan torsi gerakan forward longitudinal.

Berdasarkan gambar 17, dapat dilihat bahwa nilai torsi pada gerak forward dan reverse transversal kondisi dibebani lebih besar daripada kondisi tidak dibebani. Seperti pada picuan duty cycle $90 \%$, pada gerakan forward transversal nilai torsi kondisi tidak dibebani adalah 1,35 $\mathrm{Nm}$, sedangkan pada kondisi dibebani 1,49 Nm.

\section{Kesimpulan}

DC chopper tipe buck sudah berhasil dibuat dan telah dapat diaplikasikan pada pengatur laju putaran motor DC power window sebagai penggerak prototype overhead crane. Motor DC magnet permanen sebagai penggerak prototype overhead crane pada gerakan longitudinal dan transversal sudah dapat bekerja dengan duty cycle buck converter $60 \%$, karena tegangan yang dihasilkan sudah dapat mengontak relay yang terhubung ke motor. Secara teori semakin besar nilai duty cycle maka tegangan yang dihasilkan akan semakin besar. Tegangan keluaran terkecil bernilai 7,45 volt terjadi pada gerakan forward longitudinal kondisi dibebani dengan duty cycle $60 \%$. Tegangan keluaran terbesar bernilai 12,18 volt terjadi pada gerakan reverse transversal kondisi tidak dibebani dengan duty cycle $90 \%$. Pada motor DC magnet permanen, tegangan berpengaruh terhadap kecepatan putar motor, semakin besar nilai tegangan, kecepatan putar motor akan semakin besar. Kecepatan putar motor terkecil bernilai 46,69 rpm yang terjadi pada gerakan forward longitudinal dibebani pada duty cycle $60 \%$. Kecepatan putar motor terbesar bernilai 126,18 rpm yang terjadi pada gerakan reverse longitudinal tidak dibebani pada duty cycle $90 \%$. Secara teori pada motor DC power window, tegangan berpengaruh terhadap torsi, dimana semakin besar nilai tegangan, torsi yang dihasilkan oleh motor DC power window semakin besar. Torsi terkecil bernilai $0,96 \mathrm{Nm}$ yang terjadi pada gerakan forward transversal tidak dibebani, dengan panjang lintasan 0,88 meter dan waktu tempuh 3,66 detik serta daya keluaran $7,74 \mathrm{~W}$ pada duty cycle $60 \%$. Torsi terbesar bernilai $2,96 \mathrm{Nm}$ yang terjadi pada gerakan forward longitudinal dibebani, dengan panjang lintasan 1,2 meter dan waktu tempuh 4,79 detik serta daya keluaran $24,79 \mathrm{~W}$ pada duty cycle $90 \%$.
Berdasarkan penelitian yang penulis lakukan, penelitian ini dapat dikembangkan dengan menggunakan feedback arus sebagai kontrol arus keluaran pada DC chopper buck converter, agar nilai keluaran arus dapat dikontrol. Penelitian ini dapat dikembangkan kembali menggunakan motor jenis lain, seperti motor DC shunt, seri, compound, dan lain lain sebagai penggerak prototype overhead crane. Rangkaian kontrol IC SG3524 sebagai sinyal pemicuan pembangkit duty cycle yang bersifat analog dapat digantikan dengan menggunakan mikrokontroler yang bersifat digital, agar kinerja buck converter dapat dikendalikan dengan mode otomatis.

\section{Referensi}

[1]. Biyan Suhardanto, Mochammad Facta, Agung Nugroho. "Pembuatan DC-DC Konverter 300 Volt Jenis Buck", Transient, Vol.4, No.2, Juni 2016.

[2]. Juli Setiawan, Mochammad Facta, Bambang Winardi. "Perancangan Arus Searah Tipe Buck Pada Mode Operasi CCM dan DCM", Transient, Vol. 4 No.3, November 2017.

[3]. Ray Siddhartha, Introduction to Materials Handling. New Delhi: New Age International.

[4]. W.H. Daniel, "Power Electronics," dalam The McGrawHill Companies, Indiana, Valparaiso University, 2011.

[5]. N. L. ELECTRICAL, "Datasheet Motor CSD80A1-A," no. 0 , pp. 1-11, 2017.

[6]. IRFP460, SiHFP460 Vishay Siliconix Power MOSFET, Vishay Product Inc, 2008

[7]. T. Instruments, "SG2524, SG3524 Regulating PulseWidth Modulators," Revised february 2003.

[8]. TOSHIBA PhotocouplerTLP250, TOSHIBA Inc, 2004.

[9]. T. Wildi, "Electrical Machines, Drives, and Power System 5th Edition." 2002.

[10]. N. Mohan, Power Electronics, Second. New York: John Wiley \& Sons, Inc, 1995.

[11]. J. E. Carryer, R. M. Ohline, and T. W. Kenny, Introduction To Mechatronic Design, no. Dc. 2003.

[12]. Ari Robiul Ichsan, Machmud Effendy, Diding Suhardi. "Studi Analisa Synchronous Rectifier Buck Converter untuk Meningkatkan Efisiensi Daya pada Sistem Photovoltaic", Kinetik, Vol. 2, No. 3, Agustus 2017.

[13]. Ignatius Riwi S, Bambang Sutopo, Astria Nur Irfansyah. "Perancangan Buck Converter Sebagai Catu Daya Berbasis IC TL494 dan ATMega8535", Jurnal Penelitian Teknik Elektro Vol. 3 No. 3, Sepetember 2010.

[14]. Sulasno, Teknik Konversi Energi Listrik dan Sistem Pengaturan. Yogyakarta: Graha Ilmu, 2009.

[15]. Rashid, Muhammad H., "Power Electronics Handbook", University of Florida, Florida, 2001.

[16]. A. B. Vernandez, Mochammad Facta, Tejo Sukmadi. "Perancangan Konverter DC-DC Topologi Buck Berbasis Mikrokontroller ATMega8535 Untuk Aplikasi Heater Ekstraksi Biji Kapuk" Transient, Vol.4, No.2, Juni 2015. 